Widyaningsih Heni, Asmawi Moch., Tangkudung James. The Influence of Teaching Skills and Effective Communication on The Professional Competencies of Physical Education Teachers. Journal of Education, Health and Sport. 2020;10(1):84-89. eISSN 2391-8306. DOI http://dx.doi.org/10.12775/JEHS.2020.10.01.010

https://apcz.umk.pl/czasopisma/index.php/JEHS/article/view/JEHS.2020.10.01.010 https://zenodo.org/record/3626268

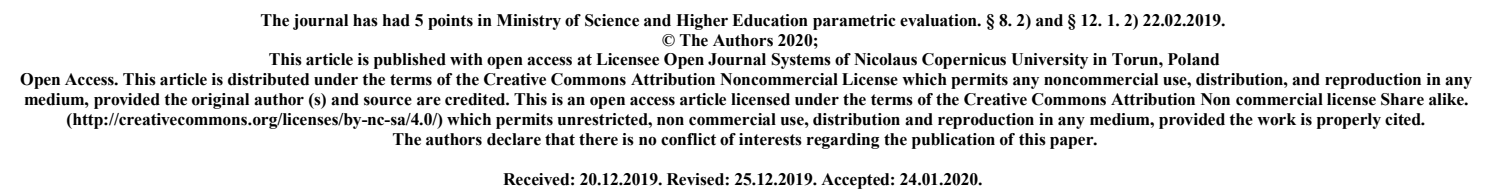

\title{
The Influence of Teaching Skills and Effective Communication on The Professional Competencies of Physical Education Teachers
}

\author{
Heni Widyaningsih ${ }^{1}$, Moch. Asmawi², James Tangkudung ${ }^{3}$ \\ ${ }^{1,2,3}$ Sport Education, Universitas Negeri Jakarta, Indonesia \\ Email: heniwidyaningsih@unj.ac.id
}

\begin{abstract}
In Indonesia, teacher should have four competencies, namely pedagogic competence, social competence, personality competency and professional competence. This study aims to determine the influence of teaching skills and effective communication on performance of physical education teachers. This study uses associative quantitative method by using multiple correlation models. The population and sample are physical education teachers who took the program of Education and Training of Professional Teacher called PLPG at Universitas Negeri Jakarta. The results of this study are (1) there is significant influence between teaching skills to performance of physical education teachers as professional competencies, (2) there is significant influence between effective communication to performance of physical education teachers as professional competencies and (3) there is significant influence between teaching skill and effective communication to performance of physical education teachers as professional competencies.
\end{abstract}

Key words: teaching skills, effective communication, physical education teacher 


\section{INTRODUCTION}

In the world of education, the implementation of quality education is very dependent on the quality of the teaching teacher. Qualified teachers are teachers who have good teaching competencies. Education is very decisive towards the progress of the nation, so education must be carried out as well as possible (Indah, et.al., 2020). The implementation of education starts from the provision of education staff to efforts to improve the quality of teaching staff. All depends on the willingness, perseverance and effort of the teacher needed to regulate the various competencies needed in carrying out his professional duties. The success of a teacher is marked by the achievement of work results that are in accordance with the teacher's work standards (Makela, \& Whipp, 2015). The general standards in the field of teacher work are stated in Law No. 14 of 2005 concerning on Teachers and Lecturers, which stipulates that Teachers are professional educators whose main tasks are to educate, teach, guide, direct, train, assess and evaluate students in early childhood education in formal education, basic education and secondary education.

A teacher is expected to be able to appear professional in carrying out their duties, because maximum effort will be an important part of the teaching process. As for one of the most important supporting factors for achieving professionalism in teaching is the presence of teaching skills that must be possessed by each individual concerned. Teaching skills is an ability that a teacher has that is related to his job. Standardized teaching skills and benchmarks for a profession can be said to be competencies. Competence is a fusion of knowledge (thinking power), attitude (heart power), and skills (physical power) which are manifested in the form of actions. In other words, competence is a combination of mastery of knowledge, skills, values and attitudes reflected in the habit of thinking and acting in carrying out their duties or jobs). It can also be said that competence is a combination of abilities, knowledge, skills, attitudes, traits, understanding, appreciation, and expectations that underlie the characteristics of a person to demonstrate work in carrying out their duties (Nurhadi, 2012).

The formulation of the above competencies contains three aspects (1) competencies as an overview of the ideal substance and material that should be required by the teacher in carrying out his work; (2) competency as a picture of real performance that shows the quality of one's mindset, attitudes and actions in carrying out their work skillfully. A teacher can succeed in mastering theoretically all the material aspects of the competencies that are taught and required; (3) competence as a result (output and outcome) of performance. Teacher competency characterizes behavior and is proficient in carrying out effective and efficient work tasks. The result is a product of one competence in carrying out their duties and jobs. So that other parties can judge someone whether in carrying out their duties and work competent and professional.

Communication does not take place in a social vacuum, but in a context, namely in a particular setting. There are many of communicator experts classify of communication based on the context. Based on the type of message content there is also based on the number of participants involved in communication. According to Richard West and Lynn H. Turner (2007), there are seven communication contexts, namely: Intrapersonal, Interpersonal, small group, organizational, public, mass media and cultural. In line with Dani Vardiansyah (2004), the context of communication by category the number of people involved in it, namely intrapersonal communication, interpersonal 
communication, group communication, public communication, organizational communication, and mass communication.

The urgency in this study is that education is an investment in human life, because through education human civilization will change (Varea, et.al., 2018). It is meant the development towards a more modern civilization. Humans as agents of change are always faced with problems to meet their needs, so there must be a standard of satisfaction from meeting those needs. Education is now a primary need for humans, therefore there must be standardization relating to education. One of the benchmarks for achieving standards in education is the quality of graduates or outcomes of students and one of the factors in creating quality graduates is the quality of the teaching staff.

\section{METHOD}

Based on previous study and research objectives, the method used in this research is descriptive method with survey techniques. Descriptive research method is a method in which the delivery of research results which examines a group of humans, an object, a condition, a system of thought, or a flash of events in the present. While surveys are investigations that are held to obtain facts from existing symptoms and find information in fact, both about social, economic or political institutions from a group or a region. For the analysis technique used is the correlational design approach, through path analysis (path analysis) using structural equations. So, the path analysis model is used to analyze the pattern of relationships between variables in order to determine the direct or indirect effects of a set of independent variables (exogenous) on the dependent variable (endogenous). The variables studied consisted of three variables consisting of two exogenous variables (free) and one endogenous variable (bound). Exogenous variables consist of Teaching Skills $\left(\mathrm{X}_{1}\right)$, Effective Communication $\left(\mathrm{X}_{2}\right)$ and Endogenous Variables Professional Competence (Y). The relationship pattern between research variables is shown in the following figure

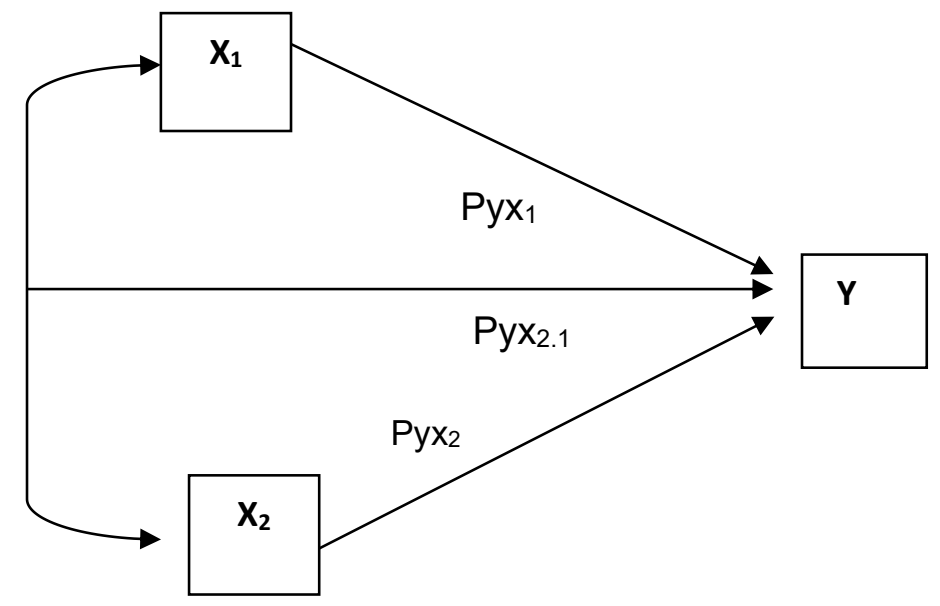

Figure 1. Exogenous variables consist of Teaching Skills $\left(\mathrm{X}_{1}\right)$, Effective Communication $\left(\mathrm{X}_{2}\right)$ and Endogenous Variables Professional Competence $(\mathrm{Y})$

Source: private document (2019) 


\section{RESULT AND DISCUSSION}

\section{Description of Variable Data Professional Competence}

Empirically the data on professional competency variables have a score range of 95 , namely with the lowest score of 22 and the highest score of 117 . Based on the results of data analysis it was found that the average score was 58.57, with a standard deviation of 28.016, median 61, mode 97, number of classes 7 and the class length as much as 14 . The next trend in the distribution of professional competence (Y) above is depicted in the histogram diagram as illustrated in Figure 2. on the below:

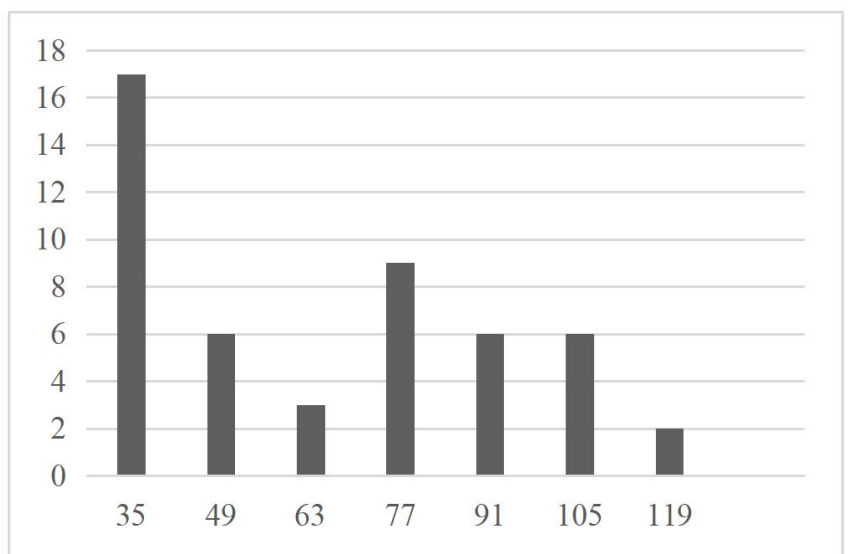

Figure 2. Histogram of Trends in Professional Competence of Physical Education Teachers Source: private document (2019)

\section{Data Description of Variable Teaching Skills}

The teaching skills variable $\left(\mathrm{X}_{1}\right)$ was measured through 30 items in the questionnaire with 49 respondents from elementary school physical education teachers. Empirically this variable has a range of scores of 34, namely with the lowest score of 100 and the highest score of 134. Based on the results of data analysis it can be stated that the average score is 115.51 , with a standard deviation of 8.766 , median 115 , mode 112 with the number of classes 7 , and the length of class 5. Furthermore, the tendency of distribution of teaching skills $\left(\mathrm{X}_{1}\right)$ of the Badminton National on National Training of physical education teacher on the histogram diagram in Figure 3 below: 


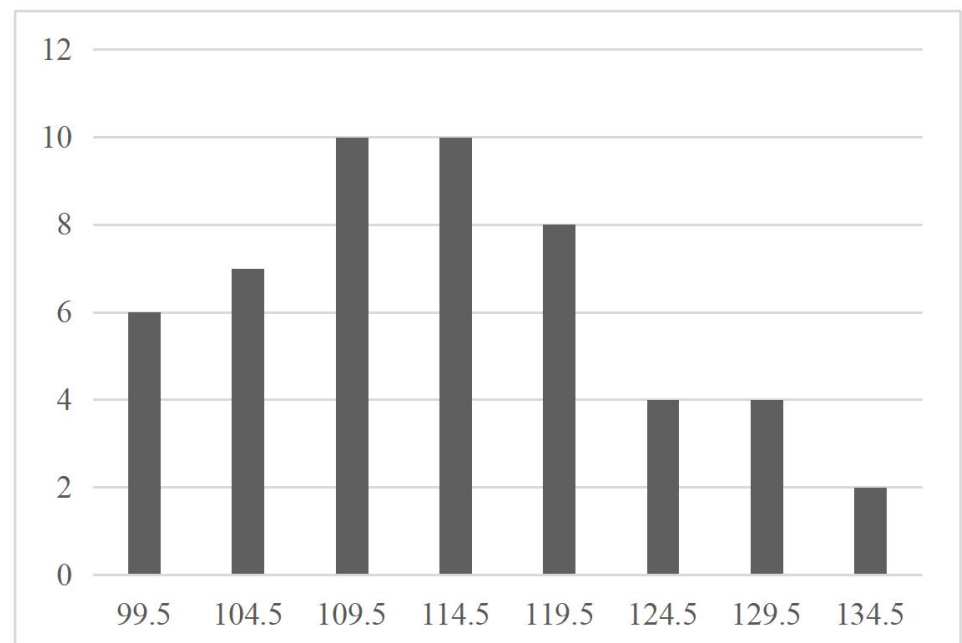

Figure 3. Histogram of Trends in teaching skills of physical education teachers. Source: private document (2019)

Interpretation of the Direct Effects of Teaching Skills on Professional Competencies. Based on the teaching skill coefficient on professional competence $(\rho 53)$, it can be seen that $\mathrm{t}_{\text {count }}$ is 1.142 and significance $0.005(<=0.05)$ and $\mathrm{t}_{\text {table }}$ at $<=0.05$ at 1.6082 , so this states that teaching skills contribute to competency professional. While the magnitude of the direct influence of teaching skills on professional competence is known through the path coefficient $\rho 53=0.222$ of 0.05 or $5 \%$. This means that teaching skills have a positive influence on sports performance by $5 \%$. Based on hypothesis testing, it is evident that teaching skills actually have a positive influence on professional competence.

\section{Description of Data Variables Effective Communication}

Effective communication variable $\left(\mathrm{X}_{2}\right)$ is measured through 30 items in the questionnaire with 49 respondents of physical education teachers. Empirically this variable has a range of scores of 25, namely with the lowest score of 114 and the highest score of 139. Based on the results of data analysis it can be stated that the average score is 124.49 , with a standard deviation of 7.151, median 124, mode 115 with the number of classes 7 , and class length 4 . Next is illustrated the tendency of effective communication distribution $\left(\mathrm{X}_{2}\right)$ physical education teacher. Interpretation of the Direct Effects of Communication on Sports Achievement. Based on the communication path coefficient on sports performance $(\rho 51)$, it can be seen that $t_{\text {count }}$ is 2.929 and significance of $0.005(<50.05)$ and $t_{\text {table }}$ at $<=0.05$ of 1.6082 , so this states that communication contributes to sports performance. While the magnitude of the direct effect of communication on sports performance is known through the path coefficient $\rho 51=0.315$ of 0.10 or $10 \%$. This means that communication has a positive influence on sports performance by $10 \%$. Based on hypothesis testing, it is evident that communication actually has a positive influence on sports performance. 


\section{CONCLUSION}

Based on the results of the study as described, this study produced findings such as (1) The direct influence of teaching skills on professional competence (2) The direct effect of effective communication on professional competence. (3) The direct influence of teaching skills and effective communication on the competency of professionalism. Based on the findings of the study it can be concluded that professional competence can be influenced by various factors such as effective teaching and communication skills and other factors.

\section{REFERENCES}

Indah Eka Purnama, Asmawi Moch, Lubis Johansyah, Dlis Firmansyah, Tangkudung James, Hanif Achmad Sofyan, \& Jufrianis. (2020). The Effectiveness of Entry Movement Exercise Model in Diving. Journal of Education, Health $\begin{array}{llll}\text { and } & \text { Sport, } & \text { 70(1), } & \text { 79-83. }\end{array}$ doi:http://dx.doi.org/10.12775/JEHS.2020.10.01.009.

Makela Kasper, \& Whipp Peter R. (2015). Career intentions of Australian physical education teachers. European Physical Education Review, 21(4), 504-520

https://doi.org/10.1177/1356336X15584088.

doi:

Nurfuadi. (2012). Profesionalisme Guru. Purwokerto: STAIN Press.

Vardiansyah, Dani. (2004). Pengantar Ilmu Komunikasi; Pendekatan Taksonomi, Konseptual, Bogor: Ghalia Indonesia.

Varea Valeria, Calvo Gustavo Gonzales, \& Alcala David Hortiguela. (2018). The influence of consumerism on Spanish physical education teachers. European Physical Education Review, 25(4), 949-963. doi: https://doi.org/10.1177/1356336X18789196

West, Richard \& Lynn H.Turner. (2007). Pengantar Teori Komunikasi. Jakarta: Salemba Humanika. 